\title{
SOCIEDADE CIVIL: o lugar e as faces do conflito
}

\section{Civil society: the place and the faces of conflict}

\author{
Ericson Sávio Falabretti
}

Doutor em Filosofia pela UFSCar. Professor do Programa de Pós-Graduação da PUCPR, Curitiba, PR - Brasil, e-mail: ericson.falabretti@pucpr.br

\section{Resumo}

Este trabalho discute como o tema sociedade civil apresenta-se na obra de Rousseau: a sua origem, as suas diferentes formas e a sua função. Examina, ainda, a idéia de que a sociedade civil estabeleceu-se como uma invenção do homem para responder aos perigos que se ofereciam à conservação da vida e da propriedade privada. Afirmamos, principalmente, que a sociedade civil nasceu como uma forma de o homem regular e manter relações de conflitos.

Palavras-chave: Opinião pública; Sociedade civil; Estado de natureza; Propriedade; Conflito.

\section{Abstract}

This work argues as the subject civil society if it presents in the work of Rousseau: its origin, its different forms and their function. It examines, yet, the idea that the civil society was established as an invention of the man to answer the dangers that are offered to the preservation of life and private property. We affirm, mainly, that the civil society was born as a way of the man regularly and maintain relations of conflicts.

Keywords: Public opinion; Civil society; State of nature; Property; conflict. 
Qual é a relação na obra de Rousseau entre o desenvolvimento moral e intelectual do gênero humano, o aparecimento da sociedade civil e a formação do pacto social? A leitura dessa questão, lugar comum de muitas análises dedicadas ao pensamento rousseauniano, indica de imediato duas coisas importantes: primeiro, fiel à cronologia dos textos do autor, encontrase aí um bom roteiro para a leitura da sua obra. É fundamental, nesse caso, passar pelos dois primeiros Discursos antes de enfrentar a letra do Contrato Social. Depois, talvez a sugestão mais importante dessa questão, a idéia de que para Rousseau os termos sociedade civil e sociedade política são significativamente distintos, apesar de intimamente implicados. Distinção que confere ao seu pensamento uma atualidade singular em comparação aos teóricos políticos do pensamento iluminista como, por exemplo, Hobbes e Locke. Vejamos brevemente, como indica Bobbio; Matteucci; Pasquino (1991, p. 1206), uma comparação com as teses de Hobbes.

Para Hobbes, de modo geral, a sociedade civil contrapõe-se ao estado selvagem e o seu nascimento supõe, de antemão, o estabelecimento de uma instituição de poder. Civilizado, num sentido equivalente ao termo cidadão, é todo aquele homem que tem direitos e deveres fundados numa lei positiva e garantidos por uma associação política: um governo. Sem a conquista dessas condições, fundamentalmente de um poder soberano - Hobbes é muito enfático sobre isso - o homem ainda estaria vivendo no estado de natureza sem proteção, sem diretos, sem leis e sem obrigação:

Quando se faz um pacto em que ninguém cumpre imediatamente a sua parte, e uns confiam nos outros, na condição de simples natureza (que é uma condição de guerra de todos os homens contra todos os homens) a menor suspeita razoável torna nulo esse pacto. Mas se houver um poder comum situado acima dos contratantes, como direito a força suficiente para impor seu cumprimento, ele não é nulo. (HOBBES, 1999, p. 116).

Já em Rousseau a sociedade civil tem, como melhor ainda veremos, o sentido de uma sociedade ordenada que antecede e funda as instituições políticas. Na sociedade civil pensada por Rousseau, o conflito entre os particulares existe, mas sem a dimensão e os motivos de um conflito permanente, "uma guerra de todos contra todos". Seja no segundo Discurso ou no Contrato Social, a formação de um pacto político supõe claramente a preexistência de uma sociedade civil. Se os homens já não estivessem previamente reunidos, uma resposta às necessidades que se impuseram à conservação da vida e aos avanços materiais e morais, não poderiam 
estabelecer um pacto político. Nesse caso, podemos dizer que o homem era um selvagem antes de ser civilizado e, ainda, viveu nessa condição muito antes de poder ostentar o título de cidadão policiado:

Um povo, diz Grotius, pode dar-se a um rei. Portanto, segundo Grotius, um povo é povo antes de dar-se a um rei. Essa doação mesma é um ato civil, supõe uma deliberação pública. Antes, pois, de examinar o ato pelo qual um povo elege um rei, conviria examinar o ato pelo qual um povo é povo, pois esse ato, sendo necessariamente anterior ao outro, constitui o verdadeiro fundamento da sociedade. (ROUSSEAU, 1978, p. 30).

No Discurso sobre as ciências e as artes não encontramos a genealogia da sociedade civil. Esse é um assunto que atravessa boa parte do Discurso sobre a desigualdade e, de modo menos enfático, também aparece no Contato Social. O que salta aos olhos é o diagnóstico vibrante e negativo que esse primeiro Discurso comporta do homem social, da própria sociedade civil e das instituições políticas. Rousseau lança mão de um grande número de fatos e acontecimentos históricos para sustentar que a sociedade civil, o homem sociabilizado e as instituições políticas mantêm entre si relações de natureza beligerantes e ambíguas. Desde a Antigüidade, o poder político, abandonado ao curso necessário dos eventos, mantém com diversos elementos da sociedade civil uma ligação de dupla implicação: sobrevive por meio da força e das ações da sociedade civil ao mesmo tempo em que trabalha para o seu enfraquecimento. Semelhante a um vampiro que para se alimentar continuamente deve cuidar da sua presa e não deixá-la fraca demais. Como, por outro lado, para não correr o risco de ser superado por ela, também não pode permitir que se fortaleça. Portanto, a trama que envolve o poder político e a sociedade civil é de mútua dependência. Assim, por exemplo, Rousseau não deixa de reconhecer que as ciências, as letras e as artes, nascidas e cultivadas no interior da sociedade civil, incutem nos homens o gosto pelas relações sociais, pelas conquistas privadas e pela urbanidade.

Mas essa expressão positiva da cultura, capaz de esclarecer os espíritos mais grosseiros, também precisa ser pensada à luz dos conflitos que se estabelecem entre as forças que formam a cidade. O que está em questão para Rousseau, crítico do Renascimento, é o uso político das artes, das letras e das ciências: quanto mais letrados são os nossos cidadãos, mais fortes são os vínculos que afirmam o gosto pela sociabilidade, mais instrumentos os homens encontram para jogar com a aparência e a dissimulação e, como o texto abaixo indica, mais facilmente são persuadidos a aceitar a condição de dependência servil ao poder político instituído: 
Enquanto o Governo e as leis atendem à segurança e ao bem estar dos homens reunidos, as ciências, as letras e a artes, menos despóticas e talvez mais poderosas, estendem guirlandas de flores sobre as cadeias de ferro de que eles estão carregados, afogam-lhes o sentimento dessa liberdade original para a qual pareciam ter nascido, fazem com que amem sua escravidão e formam assim o que se chama de povos policiados. (ROUSSEAU, 1978, p. 335).

Se o homem civil é reprovado porque é dissimulado e, como o como texto acima bem estabelece, porque "ama a sua condição de policiado", ele, por outro lado, não o é em função da sua natureza ou, mesmo, pela sua pretensa condição de cidadão. A culpa, como veremos mais adiante, nesse caso, não é da vontade do homem em ser sociável ou dissimulado, pois não dirigimos o jogo de forças que sustenta as relações de dependência entre os cidadãos, a sociedade civil e o poder político. O que está em questão são apenas o lugar e a função que o cidadão desempenha no processo formação das sociedades civis e no desenvolvimento e fortalecimento das associações políticas. Nesse caso, é fundamental admitir que essa dependência de movimentos contraditórios constitui o fundamento que parece formar o liame indissociável entre esses três elementos.

A sociedade civil criticada por Rousseau, tanto no primeiro como no segundo Discurso, em nada se parece com os modelos clássicos elencados pela teoria política tradicional. Não se encaixa, por exemplo, num modelo comunitarista ou utilitarista. Talvez, é há restrições conceituais sobre isso, a sociedade civil rousseauniana descrita nos dois primeiros Discursos esteja um pouco próxima daquilo que convencionalmente se define como um modelo individualista. $\mathrm{Na}$ verdade, o mais fundamental é, nesse momento, apenas admitir que ela não se reduz à reunião de um amontoado de pessoas desorganizadas. "[...] os estabelecimentos humanos parecem, à primeira vista, fundamentados em montões de areia movediça. Só quando o examinamos de perto, só quando removemos a areia e o pó que cobrem o edifício, percebemos a sólida base sobre a qual se ergue e se aprende a respeitar os seus fundamentos" (ROUSSEAU, 1978, p. 231).

A novidade rousseauniana consiste, antes de tudo, em mostrar que a principal característica da sociedade civil é se apresentar como um meio que utiliza o conflito para harmonizar os interesses privados dos cidadãos ou, ainda, para fazer os cidadãos agirem em função do poder político instituído. No interior da sociedade civil, todos os conflitos possíveis são insuflados: entre particulares; entre os cidadãos o Estado e a vontade particular dos governos ou das associações privadas. Portanto, a sociedade civil historicamente formada - como está dada nos dois primeiros Discursos 
- é complexa e o seu desenvolvimento e funcionamento, longe de qualquer disposição contingente, obedece a um conjunto de eventos e forças ordenados sob a lógica da necessidade e do conflito.

Acompanhemos, primeiramente, como o conflito em diferentes gradações é assumido no interior da sociedade civil. O homem poderia ter permanecido no estado de natureza, ou ainda, no período da juventude da história do mundo, vivendo em pequenas comunidades de forma simples e feliz. Poderia ter se conservado espontâneo, autor de suas próprias escolhas e livre das regras impostas pela opinião pública e pela honra. Poderia ter permanecido livre, sem necessariamente passar ao estado civil, se não fosse um conjunto de causas fortuitas que colaboraram na destruição da ordem do estado anterior: "Suponhamos os homens chegando àquele ponto em que os obstáculos prejudiciais à sua conservação no estado de natureza sobrepujam, pela sua resistência, as forças que cada indivíduo dispõe para manter-se nesse estado. Então, esse estado primitivo já não pode subsistir, e o gênero humano, se não mudasse vida pereceria" (ROUSSEAU, 1978, p. 31). Nesse caso, é preciso aceitar que as relações de conflitos são inevitáveis na medida em que são intrínsecas ao vínculo civil do qual os homens não podem escapar. Não há vida possível fora da esfera social, não podemos satisfazer às nossas necessidades sem o concurso alheio, isto é, estamos todos condenados a viver num estado de disputa contra todos aqueles que não podemos dispensar a companhia.

A vida em família, a formação da propriedade privada, a aquisição e o aperfeiçoamento da linguagem, a formação das sociedades e o estabelecimento das leis marcam, no segundo Discurso, a ordem histórica da corrupção. A história hipotética do segundo Discurso encontra seu ponto final na descrição da ordem do tempo, dos acontecimentos quando é impossível vislumbrar um outro homem que não seja aquele identificado no primeiro Discurso: dividido entre ser e parecer. O movimento da história, narrado no segundo Discurso, conduziu o homem a uma evolução, ao uso da razão, instaurou a incerteza e a desconfiança, instaurou uma desigualdade ilegítima e destituiu o homem de algo que era inerente à sua natureza, a liberdade, promoveu uma dicotomia entre dois mundos (público e privado), e determinou a existência de um homem único, porém prudente.

É nessa lenta sucessão de coisas que encontrará a solução de uma infinidade de problemas de moral e de política, que os filósofos não podem resolver. Compreenderá que o gênero humano de uma época não sendo o gênero humano de outra, esta é a razão por que Diógenes não encontrava um homem, pois ele procurava entre seus contemporâneos o homem de uma época já passada. (ROUSSEAU, 1978, p. 280). 
Mas é preciso evitar o perigo de querer naturalizar a existência da sociedade civil. O homem somente começa a fazer política quando as suas ações aparecem a um público. No estado de natureza, a coletividade praticamente inexistia, a vida era marcada pela solidão e pelo desinteresse pelo semelhante, temos apenas a manifestação de uma vida privada, com completa ausência tanto de uma moralidade, quanto de uma vida pública. Note-se então que o mito do bom selvagem, caso entendamos que essa qualificação denota uma constituição moral positiva, não é pertinente ao homem do estado de natureza rousseauniano. O selvagem nunca agia tendo em vista uma norma ou uma lei moral. Apenas encontrava-se perante o agir conforme as manifestações de sua natureza. Moralidade ou ação moral somente aparecem no plano da publicidade. Pois somente em uma vida pública o meu semelhante é objeto de um julgamento alheio, como é também para si mesmo.

Seguindo a trilha dos eventos narrados no segundo Discurso e as primeiras páginas do Contrato Social, está claro que a série de conquistas e desenvolvimentos que distanciaram os homens do estado de natureza não ocasionou diretamente o nascimento da sociedade civil, apenas criou as condições para o seu aparecimento. A sociedade civil e as associações políticas não estão inscritas no concurso natural dos eventos que determinaram o fim do estado de natureza e, muito menos, na própria natureza. Toda e qualquer associação, civil ou política, remonta sempre a uma convenção. Somente depois que o homem, conforme a narrativa rousseauniana, aprendeu a arte da metalurgia, da agricultura, tomou posse da terra e, sobretudo, desenvolveu a sua linguagem a ponto de ser capaz de persuadir os outros, é que ele encontrou as condições para criar a sociedade civil: "O verdadeiro fundador da sociedade civil foi o primeiro que, tendo cercado um terreno, lembrou-se de dizer isto é meu e encontrou pessoas suficientemente simples para acreditá-lo" (ROUSSEAU, 1978, p. 259). Portanto, diferente das mudanças e conquistas morais, intelectuais e materiais que se impuseram aos homens como resultado de uma lógica que determinava o ritmo do progresso em função das necessidades que se apresentavam, a formação da sociedade e das leis obedeceu somente necessidades e interesses que não eram naturais e, o mais importante, atendeu aos objetivos particulares de poucos homens. Muito provavelmente o nascimento da sociedade civil representa a primeira grande criação humana, a primeira intervenção racional do homem nas relações de conflito e no curso da história. Foi, de modo mais específico, um acontecimento meticulosamente projetado para legitimar aquilo - a propriedade privada - que um direito precário, seja do primeiro ocupante, da posse produtiva ou, mesmo, da força eram incapaz de 
garantir. [...] "o rico, forçado pela necessidade, acabou concebendo o projeto que foi o mais excogitado que até então passou pelo espírito humano" (ROUSSEAU, 1978, p. 269).

Portanto, a origem da sociedade civil se dá, antes de tudo, como a resposta - reação - articulada aos perigos de um conflito que ameaçava a propriedade privada e, depois, como o lugar próprio no qual o conflito deve ser vivenciado. A história da desigualdade nada mais é do que um processo contínuo de revoluções fomentado à luz de disputas. A sociedade civil, como descreve o Discurso sobre a desigualdade, é, antes de tudo, resultado desse processo. Ela já nasceu carregando em si o germe das disputas e, o que é mais importante, ao garantir no seu interior a propriedade como um direito, perpetuou a principal razão das guerras, do roubo e dos assassinatos:

Assim, os mais poderosos ou os mais miseráveis, fazendo de suas forças ou de suas necessidades uma espécie de direito ao bem alheio, equivalente, segundo eles, ao de propriedade, seguiu-se à rompida igualdade a pior desordem; assim as usurpações dos ricos, as extorsões dos pobres, as paixões desenfreadas de todos, abafando a piedade natural e a voz ainda fraca da justiça, tornaram os homens avaros, ambiciosos e maus. Erguer-se entre o direito do mais forte e do primeiro ocupante um conflito perpétuo que terminava em combate e assassinatos. A sociedade nascente foi colocada no mais tremendo estado de guerra. (ROUSSEAU, 1978, p. 268).

Desse modo, todas as sociedades civis, marcadas desde a suas origens pelas disputas, criam mecanismos para fortalecê-las entre os seus cidadãos. Não há como fugir da sua vocação. A concorrência é insuflada em todas as situações: no lazer, na economia, na política, na vida privada e na moral. Os homens apreendem desde cedo que a falta de transparência nas relações, a separação entre intenção e discurso, a mentira, a prudência e a polidez são instrumentos necessários para se conduzir num meio que se ordena e progride em função das disputas, na sociedade civil a honra cabe somente aos primeiros: "Já desde os primeiros anos, uma educação insensata orna nossa espírito e corrompe o nosso julgamento" (ROUSSEAU, 1978, p. 347).

Mas as relações de conflito também são internas. O homem vive a disputa como uma experiência subjetiva. Os interesses particulares e os deveres públicos, por exemplo, não impõem apenas um tipo de comportamento ou de juízo. Os interesses da sociedade civil e das associações políticas que atuam na condução da vida trabalham, sobretudo, para distanciá-lo da posse de qualquer 
certeza subjetiva. Há um conflito, um elemento de dominação que se perpetua no interior do cidadão e consiste em separá-lo de si mesmo. A opinião pública, a voz oficial da sociedade civil, é o fundamento de toda e qualquer certeza. Nesse sentido, o homem social vive intimamente um conflito que opõe o seu interior à força da opinião pública. Não podemos mais dizer que o homem civil existe e vive por ele mesmo, mas somente em relação aos outros, ao que estes pensam dele. Está sempre se colocando à mercê das opiniões e dos preconceitos da opinião púbica.

Por meio da força da opinião pública há uma cumplicidade entre o discurso do homem sociabilizado e uma intenção, que apesar não ser a mesma do homem natural do segundo Discurso, faz o homem social, separado da sua essência, parecer único. A transparência perdida não se refere fundamentalmente à impossibilidade de reconhecer os sentimentos e as intenções do semelhante na sua fala, no seu comportamento em geral, mas à impossibilidade do próprio sujeito em reconhecer os seus mais naturais e verdadeiros sentimentos. Esses estão sufocados pela dissolução dos costumes, pela corrupção do gosto, pela ditadura da opinião pública.

Na Carta a D'Alembert, ao se opor à idéia de se instaurar novamente um teatro em Genebra, Rousseau afirmando que o teatro, ao contrário do que afirmava D'Alembert, traz mais prejuízos do que benefícios para a cidade, quando se pensa que ele mais incita vícios do que virtudes, revela-nos uma espécie de comprometimento essencial, por parte dos homens, com a opinião pública. Uma voz que fala e age interiormente. Ela não consiste apenas em um discurso mascarado de retórica com o objetivo de agradar os outros. Falando interiormente, ela é a própria manifestação de uma intenção, de um desejo, de um sentimento que, se não são naturais, são, nesse caso, os únicos que os homens têm acesso e pelos quais regulam e conduzem as suas vidas.

Quando pode, então, o governo agir sobre os costumes? Respondo que através da opinião pública. Se na solidão nossos hábitos nascem de nossos próprios sentimentos, na sociedade eles nascem da opinião dos outros. Quando não se vive em si mesmo, mas nos outros, são os julgamentos deles que ordenam tudo; nada parece bom ou desejável aos particulares além do que o público aprovou, e a única felicidade conhecida pela maior parte dos homens é ser considerado feliz. (ROUSSEAU, 1993, p. 81).

O sujeito, separado dele mesmo, transformado em cidadão, constrói a sua nova unidade fora si: na sociedade civil. Nesse sentido, o problema do mal, como notam Cassirer e Starobinski, mudou de pólo. Se o mal antes era concebido como ato exclusivamente forjado pela natureza humana ou, conforme 
a sagrada escritura, um pecado original cuja culpa é do homem e sobre o qual a humanidade inteira, conseqüentemente, deve expiá-lo; agora, com Rousseau, o homem é destituído da responsabilidade da origem do mal, que pertence, sim, à história e à sociedade civil, que enquanto um corpo coletivo oprime as intenções subjetivas. A sociedade civil, o convívio social, por sua disposição, impede, entre outras coisas, que os homens enquanto indivíduos desenvolvam relações transparentes; que possam agir, por exemplo, de maneira honesta e seus atos sempre estejam em conformidade com intenções puras e verdadeiras. Se o homem sociabilizado é falso, se age somente movido por interesses particulares e egoístas, mesmo quando aparentemente faz o bem, se a prudência, enquanto cálculo, deve imperar na condução da vida social como uma necessidade determinante para que a vida possa perdurar, não significa que o homem em si seja mal, mas somente que a história e a sociedade (da forma como se constituiu ao longo dessa mesma história factual), por suas características, tanto construíram de maneira determinante um homem prudente que em nada se parece com o homem natural, quanto maquinaram a instauração do mal. Como nos indica a leitura de Starobinski, somos isentos da culpa na medida em que a história cometeu o pecado, e que a sociedade escolheu mudar o homem:

O mal se produz pela história e pela sociedade, sem alterar a essência do indivíduo. A culpa da sociedade não é a culpa do homem essencial, mas a do homem em relação. Ora, com a condição de dissociar o homem essencial e o homem em relação, com a condição de separar sociabilidade e natureza humana, pode-se atribuir ao mal e à alteração histórica uma situação periférica em relação à permanência central da natureza original. (STAROBINSKI, 1991, p. 31).

Portanto, a corrupção moral dos homens ou das instituições civis e políticas não é uma contingência histórica fomentada pela vontade dos homens. A culpa está na história, nas sociedades e na dependência recíproca. O mal, como não poderia deixar de ser, obedece a um jogo dialético no qual os opostos sobrevivem na medida em permanecem continuamente em conflito.

Mas essa relação entre o poder político e a sociedade civil é perigosa também para a sociedade política. A dependência nessas situações, como já adiantamos anteriormente, é mútua. Quanto mais o homem interior se corrompe, mais a sociedade civil se enfraquece e mais o poder o poder político se rende aos interesses privados. Pois o sangue que alimenta também cria dependência e, nesse caso, tem o poder de envenenar. Rousseau não deixa de reconhecer que o desenvolvimento multifacetado da sociedade civil com suas associações privadas 
sempre em disputas e, fundamentalmente, o incremento das letras, das artes e do luxo como elementos de sofisticação e fortalecimento dos liames sociais induzem os homens à corrupção moral e determinam o enfraquecimento da própria sociedade civil e do poder político. Ao longo do primeiro Discurso, sempre apoiado na história, a relação se mantém constante: o nascimento e o fortalecimento dos governos despóticos, o enfraquecimento das instituições políticas ocorre concomitantemente ao aumento da corrupção moral dos homens e à multiplicação das associações particulares no interior da sociedade civil. É evidente nesse aspecto o exemplo de Roma: "Essa capital do mundo cai, finalmente, sob o jugo que impusera a tantos povos e o dia de sua queda foi aquele em se deu a um dos de seus cidadãos o arbitro do bom gosto" (ROUSSEAU, 1978, p. 338).

O que temos então é um círculo vicioso que aparece como lei da própria história. Quanto maior for a corrupção moral dos cidadãos forjada no interior da sociedade civil, seja pelos costumes ou pela força dos governos despóticos, mais perto estaremos da dissolução total das instituições políticas. Quanto mais fracas forem as instituições políticas, mais longe estaremos de poder usufruir uma condição civil fundada nos direitos de igualdade, de liberdade e da transparência nas relações humanas. É justamente essa a disposição de interesses conflitantes que os pactos civil e político, propostos pelos ricos aos pobres, fizeram nascer e se perpetuar: "Você tem necessidade de mim porque sou rico e você é pobre; façamos então um acordo: permitirei que você tenha a honra de me servir, desde que me seja dado o pouco que me resta, em troca do meu comando (ROUSSEAU, 1996, p. 56). Na verdade, a condição de desigualdade civil e a dissolução política das instituições, como bem estabelece Rousseau no Discurso sobre economia política, ocorrem de maneira mais evidente na media em que o abuso privado das leis e das instituições políticas se perpetua no interior da sociedade civil pela indiferença e pela corrupção moral dos cidadãos: "A pátria não pode subsistir sem a liberdade, nem a liberdade sem a virtude, nem a virtude sem os cidadãos..." (ROUSSEAU, 1996, p. 38).

Por isso mesmo, na obra de Rousseau, a formação de um pacto político é imperativa. Mas Rousseau não é um teórico reformista. O pacto social não visa re-fundar a sociedade civil ou, ainda, recuperar individualmente os homens de uma alienação histórica. Uma sociedade que precisa ser re-fundada ou, ainda, um homem que precisa ser recuperado não serve ao Contrato Social:

A maioria dos povos, como dos homens, só são dóceis na juventude; envelhecendo, tornam-se incorrigíveis. Desde que se estabelecem costumes e se enraízam os preconceitos, constitui empresa perigosa e vã 
querer reformá-los. O povo nem sequer admite que se toque em seus males para destruí-los, como aqueles doentes, tolos e sem coragem, que tremem em presença do médico. (ROUSSEAU, 1978, p. 60).

Mas se o pacto social é essencial é, ainda, preciso dizer o que, de modo geral, será diferente na sociedade civil que adere ao Contrato Social em relação àquela sociedade civil articulada pelos ricos e perpetuada historicamente. Primeiro é preciso lembrar que as duas não estão inscritas na natureza e só passam a existir a partir de convenções. A diferença está em que a primeira foi inventada para regular os conflitos e, como descreve o segundo Discurso, transformar uma conquista privada, a propriedade, em um direito. Já a sociedade civil que adere ao Contrato Social tem como premissa básica a idéia de que todos os direitos são, a partir do momento em que o pacto se realiza, estabelecidos somente pelo poder soberano. Na perspectiva de Rousseau, todos os direitos e conquistas anteriores ao pacto social são abandonados em função da alienação total de cada contratante: "Essas cláusulas, quando bem compreendidas, reduzem todas a uma só: alienação total de cada associado, com todos os seus direitos...." (ROUSSEAU, 1978, p. 32). A própria sociedade civil, anterior à sociedade política, não deve mais existir como antes. Há, a partir da formação do pacto social, o nascimento de um poder soberano - a vontade geral - que deve suplantar a força e os interesses de todas as vontades particulares para que as relações de conflito não tenham mais lugar no interior da sociedade civil. A alienação sem reservas supõe que o novo pacto social não se estabelece em função de qualquer interesse privado, seja de uma pessoa ou, ainda, de um grupo de pessoas.

Outra diferença importante está no fato de que na nova sociedade civil formada pelo Contrato Social todas as associações particulares devem ser combatidas, seja por meio da eliminação ou da maior multiplicação possível de associações. Pois essas associações particulares estabelecem relações mútuas de conflito, opõem-se ao estado e, talvez, a sua influência mais perniciosa, contaminam a vontade e o julgamento dos cidadãos. Rousseau quer evitar que os cidadãos decidam e participem de sufrágios influenciados pela opinião pública: "Importa, pois, para alcançar o verdadeiro enunciado da vontade geral, que não haja no Estado vontade particular e cada cidadão só opine de acordo consigo mesmo" (ROUSSEAU, 1978, p. 47).

Porém a distinção mais fundamental está, sobretudo, naquilo que permite romper com os motivos de conflito: a constituição da vontade geral como um poder soberano, inalienável e indivisível. Um poder que se relacione igualmente com todos os cidadãos, que não concede favores privados, que não 
aquiesça aos interesses de uma minoria e, sobretudo, que conserve as suas ações e interferência nos rígidos limites da sua finalidade. Somente por meio dessa constituição do poder soberano será possível garantir a liberdade e a igualdade e, por conseqüência, uma sociedade civil na qual as relações de conflito sejam, ainda que se mostre impossível extinguí-las, conservadas no menor grau possível e reguladas conforme as regras do direito.

\section{Referências}

BOBBIO, Norberto; MATTEUCCI, Nicola; PASQUINO Gianfranco. Dicionário de política. Brasília: Universidade de Brasília, 1991. p. 1206-1210.

HOBBES, Thomas. O Leviatã. São Paulo: Nova Cultural, 1999.

ROUSSEAU, Jean-Jacques. Do contrato social (a). Discurso sobre a origem e os fundamentos da desigualdade entre os homens (b). Discurso sobre as ciências e as artes (c). Ensaio sobre a origem das línguas (d). São Paulo: Abril Cultural, 1978. (Coleção Os Pensadores).

Carta a D‘Alembert. Campinas: UNICAMP, 1993.

Discurso sobre a economia política. Petrópolis, RJ: Vozes: 1996.

STAROBINSKI, Jean. Jean-Jacques Rousseau: a transparência e o obstáculo. São Paulo: Companhia das Letras, 1991.

Recebido: $12 / 01 / 2008$

Received: 01/12/2008

Aprovado: $23 / 02 / 2008$

Approved: 02/23/2008 